\title{
Lactobacillus sp and some fungi from termite nests on kolanut trees had mild antagonistic effects against pathogens isolated from paediatric patients
}

\author{
${ }^{* 1}$ Afolami, O. I., ${ }^{2}$ Arogunjo, A. O., ${ }^{2}$ Oladunmoye, M. K.,${ }^{3}$ Owoyemi, O. O., ${ }^{2}$ Aribisala, J. O., \\ ${ }^{2}$ Ajayi-Moses, O. B., ${ }^{2}$ Gabriel, P. O., ${ }^{2}$ Bhadmus, O. C., ${ }^{2}$ Wasiu, O. S., ${ }^{2}$ Arogundade, I. O., \\ ${ }^{2}$ Aiyenuro, E. A., and ${ }^{2}$ Akinwumi, I. M.
}

\begin{abstract}
${ }^{1}$ Department of Biological Sciences, Michigan Technological University, 49931, Houghton, MI, USA ${ }^{2}$ Department of Microbiology, Federal University of Technology, P.M.B. 704, Akure, Ondo State, Nigeria ${ }^{3}$ Department of Microbiology, Achievers University, P. M. B. 1030, Owo, Ondo State, Nigeria Correspondence to: afolamiolufemiifeoluwa@gmail.com or oafolami@mtu.edu
\end{abstract}

\begin{abstract}
:
Background: Residents in a rural suburb of Akure jettisoned antibiotic treatment; sought alternative cure to rising incidence of paediatric infections in 2017 from local herbal dealers, with many residents claiming of better treatment response. We investigated these claims since the local herbal formula included kola nut barks and ground termites.

Methodology: Microorganisms associated with termite nests on kola nut trees in the affected community were characterized and identified using standard techniques. The Kirby Bauer disk diffusion was used to evaluate the susceptibility of the bacterial isolates to selected antibiotics. Plasmid profile of multiple antibiotic resistant bacterial isolates (MDRIs) was determined by the Birnboim and Doly method while post plasmid curing antibiotic susceptibility was performed on the MDRIs against the same selected antibiotics. The microorganisms were also evaluated for possible antagonistic effects against Salmonella sp, Staphylococcus aureus and Streptococcus pyogenes isolated from paediatric patients during the period of study using previously described methods.

Results: Bacteria (Corynebacterium sp, Streptococcus sp, Acinetobacter $\mathrm{sp}$ and Lactobacillus sp) and fungal (Geotrichum condidum, Aspergillus niger, Fusarium oxysporum and Fusarium fujikuroi) were isolated from the termite nests. The antibiotic susceptibility revealed that Corynebacterium sp and Streptococcus sp were multiply antibiotic resistant, and this was confirmed to be plasmid mediated based on plasmid analysis and curing. The Lactobacillus sp, Aspergillus niger, Fusarium fujikuroi and Geotrichum condidum exhibited mild antagonisms against Staphylococcus aureus, Salmonella sp and Streptococcus pyogenes isolated from paediatric patients.

Conclusion: This study suggests that termite nests on kola nut trees contain microbes that possess antagonistic actions against pathogens from paediatric patients and that some bacteria associated with termite guts may pose significant risk of increased antibiotic resistance if implicated in human infections.
\end{abstract}

Keywords: Termite nests, Resistance, Antagonistic microbes, Termites, Plasmid, Kola nut tree

Received July 14, 2019; Revised January 4, 2020; Accepted January 5, 2020

Copyright 2020 AJCEM Open Access. This article is licensed and distributed under the terms of the Creative Commons Attrition 4.0 International License (http://creativecommmons.org/licenses/by/4.0), which permits unrestricted use, distribution and reproduction in any medium, provided credit is given to the original author(s) and the source.

\section{Lactobacillus sp et certains champignons provenant de nids de termites sur les arbres de kolanut ont eu de légers effets antagonistes contre les agents pathogènes isolés de patients pédiatriques}

\author{
${ }^{* 1}$ Afolami, O. I., ${ }^{2}$ Arogunjo, A. O., ${ }^{2}$ Oladunmoye, M. K., ${ }^{3}$ Owoyemi, O. O., ${ }^{2}$ Aribisala, J. O., \\ ${ }^{2}$ Ajayi-Moses, O. B., ${ }^{2}$ Gabriel, P. O., ${ }^{2}$ Bhadmus, O. C., ${ }^{2}$ Wasiu, O. S., ${ }^{2}$ Arogundade, I. O., \\ ${ }^{2}$ Aiyenuro, E. A., et ${ }^{2}$ Akinwumi, I. M.
}




\footnotetext{
${ }^{1}$ Département des sciences biologiques, Michigan Technologique University, 49931, Houghton, MI, USA

${ }^{2}$ Département de microbiologie, Université fédérale de technologie, P.M.B. 704, Akure, État d'Ondo, Nigéria

${ }^{3}$ Département de microbiologie, Université Achievers, P. M. B. 1030, Owo, État d'Ondo, Nigéria Correspondance à: afolamiolufemiifeoluwa@gmail.com ou oafolami@mtu.edu
}

\section{Abstrait:}

Contexte: Les résidents d'une banlieue rurale d'Akure ont abandonné le traitement antibiotique; ont recherché un remède alternatif à l'augmentation de l'incidence des infections pédiatriques en 2017 auprès des vendeurs de plantes locales, de nombreux résidents affirmant une meilleure réponse au traitement. Nous avons étudié ces allégations, car la formule à base de plantes locales comprenait des écorces de noix de kola et des termites moulus.

Méthodologie: Les micro-organismes associés aux nids de termites sur les arbres de noix de kola dans la communauté affectée ont été caractérisés et identifiés à l'aide de techniques standard. La diffusion sur disque de Kirby Bauer a été utilisée pour évaluer la sensibilité des isolats bactériens aux antibiotiques sélectionnés. Le profil plasmidique de plusieurs isolats bactériens résistants aux antibiotiques (MDRI) a été déterminé par la méthode de Birnboim et Doly tandis qu'une sensibilité aux antibiotiques après polymérisation du plasmide a été réalisée sur les MDRI contre les mêmes antibiotiques sélectionnés. Les micro-organismes ont également été évalués pour d'éventuels effets antagonistes contre Salmonella sp, Staphylococcus aureus et Streptococcus pyogenes isolés de patients pédiatriques pendant la période d'étude en utilisant les méthodes décrites précédemment.

Résultats: Des bactéries (Corynebacterium sp, Streptococcus sp, Acinetobacter sp et Lactobacillus sp) et fongiques (Geotrichum condidum, Aspergillus niger, Fusarium oxysporum et Fusarium fujikuroi) ont été isolées des nids de termites. La sensibilité aux antibiotiques a révélé que Corynebacterium sp et Streptococcus sp étaient multi-résistants aux antibiotiques, et cela a été confirmé comme étant médié par les plasmides sur la base de l'analyse et du durcissement des plasmides. Les Lactobacillus sp, Aspergillus niger, Fusarium fujikuroi et Geotrichum condidum présentaient de légers antagonismes contre Staphylococcus aureus, Salmonella sp et Streptococcus pyogenes isolés de patients pédiatriques.

Conclusion: Cette étude suggère que les nids de termites sur les arbres de noix de kola contiennent des microbes qui possèdent des actions antagonistes contre les agents pathogènes des patients pédiatriques et que certaines bactéries associées aux intestins des termites peuvent poser un risque significatif d'augmentation de la résistance aux antibiotiques si elles sont impliquées dans des infections humaines.

Mots-clés: nids de termites, résistance, microbes antagonistes, termites, plasmidique, arbre à noix de Kola

\section{Introduction:}

Termites are social insects that live in enclaves known as termite nests or "termitaria" $(1,2)$. They belong to the order Isoptera with more than 1800 species in 200 genera $(3,4)$. They form their nests using mud, gut exudates, secretions and faeces $(5,6)$. In various rural settlements of western Nigeria, the termite specie Odontotermes badius is predominant and serves as food supplement for local residents (6). Certain bacteria form part of termite gut flora and aid the digestion of food in termite guts $(1,2)$. However, fungi are also present in termite guts either through ingestion of infested food or propagating fungal spores $(1,5)$. Conversely, studies have recently linked interactions existing between termites and microorganisms inhabiting their guts with respect to the tree environment on which they live $(1,6)$. This has necessitated investigation into the termite microbiota and the types of microbes associated with their nests $(3,4)$.

Kola nuts (Cola sp) are widely cultivated in West Africa because they serve as natural stimulants that suppress fatigue (7). In Western Nigeria, the species, C. nitida is widely cultivated in various farm settlements for various purposes and this tree species harbor vast reserves of termites, since kola nut is an excellent source of soft wood (7).

Our field correspondence with local residents in a suburb of Akure, Nigeria in 2017 revealed that due to rising incidence of paediatric infections, the inhabitants jettisoned known antibiotics and sought alternative medical help from local herbal concoction dealers, with claims of better treatment response from the use of these concoctions in affected infants. These claims from use of local medicinal formula which included kola nut barks and ground termites were widely uncorroborated scientifically. In view of this, our study sought to identify microorganisms from termite nests on kola nut trees in the affected community, evaluate possible antagonistic effects of these microbes against clinical isolates of paediatric importance, and raise public health awareness of associated risks with use of these herbal concoctions.

\section{Materials and methods:}

\section{Description of study location}

The study area is Ipogun, a very small community with dispersed settlements. It is a 
suburb of Akure metropolis, Nigeria at $7^{\circ} 11^{\prime} \mathrm{N}$ $7^{\circ} 12^{\prime} \mathrm{N} / 5^{\circ} 4^{\prime}$ E $5^{\circ} 9^{\prime} \mathrm{E}$ coordinates (8).

\section{Sample collection and processing}

We designated kola nut plantations in the study area as sampling points for sample collection in September 2017. A total 20 dead termite aggregate samples from termite nests on kola nut trees in the study location were collected using guidelines described by Barreto et al., (9). The samples were stored under airtight ice packs and analyzed microbiologically within 4 hrs of collection (10).

\section{Isolation of microorganisms from prepared samples}

Sample preparation and isolation of microorganisms was according to Afolami et al. (1). Sterile normal saline was used as diluent and $1.0 \mathrm{~g}$ of sample stocks was weighed into $1.0 \mathrm{ml}$ of the diluent for a serial dilution process and four dilutions were obtained for a pour plate technique. Thereafter, $1 \mathrm{ml}$ of the last dilution was used to inoculate already prepared nutrient agar and potato dextrose agar plates containing $250 \mathrm{mg}$ chloramphenicol (for total filamentous fungi count). Bacterial cultures were incubated at $37^{\circ} \mathrm{C}$ for $24 \mathrm{hrs}$ and fungi at $26 \pm 2{ }^{\circ} \mathrm{C}$ for $3-5$ days $(1,2)$.

\section{Identification of bacterial isolates}

Identification of bacterial isolates was done using methods of Afolami et al., (1) and Aribisala et al., (2). Subcultures of distinct colonies were identified by gram reaction and biochemical tests such as catalase, motility, sugar fermentation (glucose, sucrose, lactose and mannitol), triple sugar iron, methyl red/voges proskauer test, oxidase and spore staining tests. The identified isolates were freshly subcultured on MacConkey and Bile Esculin agar plates, and incubated at $37^{\circ} \mathrm{C}$ for 24hours (11).

\section{Identification of fungi isolates}

The authors used methods described in Samson et al., (12) and Onifade et al., (13) for identification of fungi isolates and compared the cultural and microscopic characteristics of fungal mycelia with the available literature using the Compendiums for Air, Soil, Food and Indoor fungi $(12,13)$. The cultural and micromorphological properties of isolated fungi were obtained through microscopy of stained mycelia with cotton blue in Lactophenol dye (13). Photomicrographs of different mycelium clones were juxtaposed with matching information contained in the available literature for air and soil fungi as described in Onifade et al., (13).

\section{Antibiotic susceptibility of bacterial isolates}

The Kirby Bauer disk diffusion test was used to evaluate invitro activity of selected antibiotics against the bacterial isolates on Mueller Hinton (MH) agar. An $18 \mathrm{~h}$ old broth culture of each isolate was standardized with $0.5 \mathrm{McF}$ arland standards and plated on $\mathrm{MH}$ agar using sterile swabs as previously described (14). The selected antibiotic disks (AB Biodisk, Solna, Sweden) from seven different antibiotic classes used were amoxicillin $(25 \mu \mathrm{g})$, erythromycin $(15 \mu \mathrm{g})$, ofloxacin $(5 \mu \mathrm{g})$, ciprofloxacin $(5 \mu \mathrm{g})$, pefloxacin $(5 \mu \mathrm{g})$, cotrimoxazole $(25 \mu \mathrm{g})$, ceftriaxone $(30 \mu \mathrm{g})$, gentamycin $(10 \mu \mathrm{g})$, streptomycin $(10 \mu \mathrm{g})$ and chloramphenicol $(15 \mu \mathrm{g})$.

The antibiotic disks were gently placed on the plates and incubated for 24hours at $37^{\circ} \mathrm{C}$. The diameter of zone of inhibition of each isolate was measured with a calibrated ruler and interpreted as sensitive, intermediate or resistant according to the guidelines of the National Committee for Clinical Laboratory Standards (15) while Staphylococcus aureus ATCC 25923 was used as control strain. Test isolates with resistance to more than two classes of antibiotics were designated as multiple antibiotics resistant $(14,16)$.

\section{Plasmid profile analysis of MDRIs}

Plasmid extraction and analysis from the multiple antibiotic resistant bacterial isolates (MDRIs) was carried out using alkaline lysis method (Zymogen, UK) as previously described by Akingbade et al., (16). Plasmid extraction solution containing $20.0 \mathrm{mM}$ sodium acetate and 2.0mM EDTA adjusted to $\mathrm{pH} 7.8$ using $10 \%$ acetic acid was prepared with a sample buffer containing $25 \%$ sucrose, $5.0 \mathrm{mM}$ sodium acetate and $0.05 \%$ bromophenol blue. Electrophoresis of plasmid DNA was done on $0.9 \%$ agarose gel stained with gr-Green dye $(1 \mu \mathrm{l} / \mathrm{ml})$ at room temperature while pBR322 DNA/BsuRI (HaeIII) was used as marker. After the run time, gel was observed under UV transillumination and analyzed using a photo documentation system.

\section{Plasmid curing of MDRIs}

The curing of resistant plasmids from the MDRIs was done overnight by using the methods of Birnboim and Dolly (17) and Vivyan et al., (11). Antibiotic susceptibility testing of MDRIs post-plasmid curing was carried out with the same set of antibiotic disks (AB Biodisk, Solna, Sweden). 


\section{Antagonistic assays}

All the isolates (bacteria/fungi) were evaluated for possible antagonistic effects against clinical pathogens (Salmonella sp, Staphylococcus aureus and Streptococcus pyogenes) isolated from paediatric patients and obtained from the Department of Laboratory Services, Ondo State Specialist Hospital, Akure, Nigeria. These pathogens were adjudged to have had direct impact on the rising incidence of paediatric infections in Akure suburbs at the time of the research. The Fokkema and Heuvel (18) method was used in evaluating antagonistic potentials of fungal isolates while the methods described by Afolami et al., (1) and Aribisala et al., (2) were used to evaluate antagonistic potentials of bacterial isolates against the clinical pathogens. The susceptibility cutoffs in the assays were determined by susceptible-dosedependent criteria of the 2012 Clinical and Laboratory Standards Institute (19) and as described by Jabeen et al., (20). The inhibition zones were denoted as positive (+ve) at $\geq 16.00 \mathrm{~mm}$, intermediate (I) at $11.00-15.00$ $\mathrm{mm}$ and negative (-ve) at $\leq 10.00 \mathrm{~mm}(1,27)$. Candida parapsilosis ATCC 22019 and Haemophilus influenzae ATCC 49247 were used as control strains in the antagonistic assays.

\section{Data analysis}

The diameters of zone of inhibition for the antagonistic assays were obtained by means of triplicate values and separated using Duncan's New Multiple Range test at $p<0.05$ level of significance (and 95\% confidence interval) to determine whether they were significant or not.

\section{Results:}

The bacterial isolates across sampling points are shown in Tables 1 and 2. A total of forty-three bacteria isolates; Corynebacterium sp $(n=9)$, Lactobacillus sp $(n=17)$, Acinetobacter sp $(n=10)$ and Streptococcus sp $(n=7)$, and 22 fungi isolates; Aspergillus niger $(n=8)$, Fusarium oxysporum $(\mathrm{n}=6)$, Fusarium fujikuroi $(n=5)$ and Geotrichum condidum $(n=3)$ were recovered from the samples.

The highest zone diameter of inhibition to antibiotics by the bacterial isolates was $20.35 \pm 1.28 \mathrm{~mm}$ while the lowest zone was $3.20 \pm 1.08 \mathrm{~mm}$. The susceptibility patterns of the isolates are denoted as susceptible (S), resistant (R) and intermediate (I) in Tables 3 6. As shown in Table 3, two of the four bacteria genera/species (Corynebacterium sp, and Streptococcus sp) were multiple antibiotic resistant isolates (resistant to more than two classes of antibiotics tested). A representative isolate from each genus was profiled for plasmid analysis as shown in Fig 1.

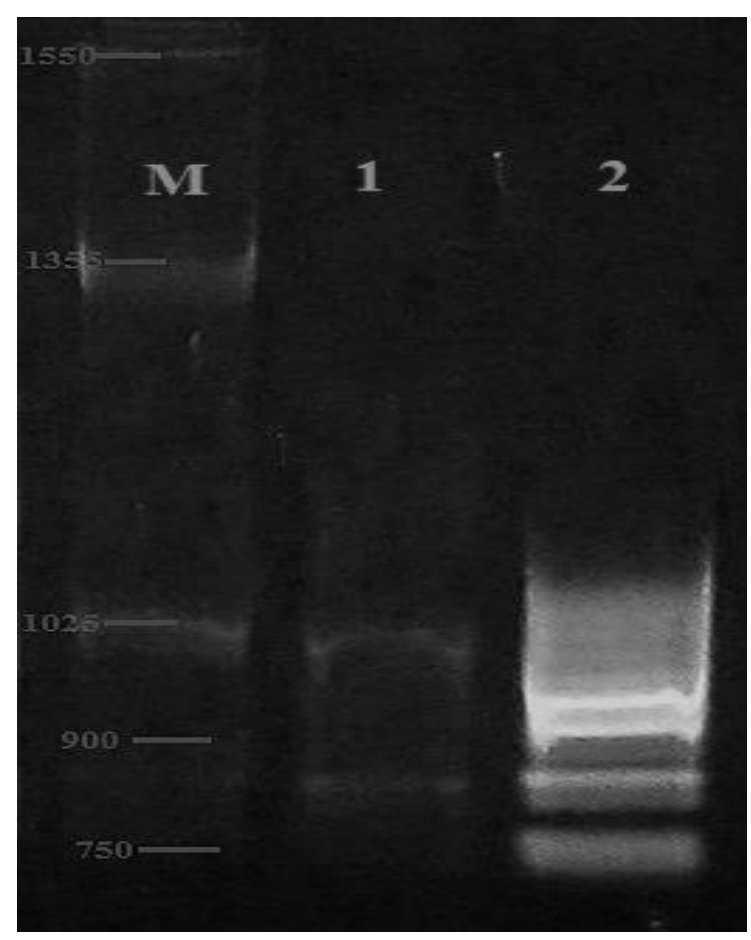

Fig 1: The electropherogram of plasmids of the MDRIs 1 = Corynebacterium sp, 2 = Streptococcus sp, $\mathrm{M}=$ molecular marker in kilobase pair

The antagonistic features (inhibitory effects) of the bacterial isolates against the pathogens obtained from paediatric patients (Salmonella sp, Staphylococcus aureus, and Streptococcus pyogenes) are shown in Table 4 while the antagonistic features (inhibitory effects) of the fungi isolates against these pathogens are shown in Table 5. Only Lactobacillus sp among the bacterial isolates had mild antagonism against the pathogens with inhibition zone ranging from $12.82 \pm 1.68$ to $16.19 \pm 1.21 \mathrm{~mm}$, while the fungi (Fusarium fujikuroi and Geotrichum condidum) had antagonistic activity against the pathogens with inhibition zones ranging from $11.91 \pm 1.66$ to $18.91 \pm 1.33 \mathrm{~mm}$.

The zones of inhibition and susceptibility patterns of the MDR isolates after plasmid curing in Table 6 showed the two MDR bacteria genera (Corynebacterium sp, and Streptococcus $\mathrm{sp}$ ) to be susceptible, which confirms that their multidrug resistance property was plasmid mediated. 
Table 1: Morphological and biochemical identification of bacterial isolates from samples analyzed

\begin{tabular}{|c|c|c|c|c|c|c|c|c|c|c|c|c|c|}
\hline \multirow[t]{2}{*}{ Isolates } & \multirow{2}{*}{$\begin{array}{l}\text { Gram } \\
\text { Stain }\end{array}$} & \multicolumn{5}{|c|}{ Sugar Fermentation } & \multirow[t]{2}{*}{ O/C } & \multirow{2}{*}{$\begin{array}{l}\text { M.t./ } \\
\text { Sp. T }\end{array}$} & \multirow[t]{2}{*}{ MR/VP } & \multicolumn{3}{|c|}{ Growth on Media } & \multirow{2}{*}{$\begin{array}{l}\text { No } \\
\text { of isolates }\end{array}$} \\
\hline & & Lac & Glu & Suc & Mann & TSI & & & & NA & $\operatorname{Mac} A$ & YEA & \\
\hline A. sp & $\begin{array}{l}\text { +ve } \\
\text { (bacilli } \\
\text { rods) }\end{array}$ & -ve & tve & tve & $+v e$ & $\mathrm{~A} / \mathrm{G}$ & $\begin{array}{l}\text { +ve/ } \\
+ \text { ve }\end{array}$ & $\begin{array}{l}\text { +ve/ } \\
+\mathrm{ve}\end{array}$ & -ve/+ve & $\begin{array}{l}\text { Cream/ } \\
\text { raised }\end{array}$ & $-v e$ & -ve & 10 \\
\hline St. $\mathrm{sp}$ & $\begin{array}{l}\text { +ve } \\
\text { (bacilli } \\
\text { rods) }\end{array}$ & tve & tve & tve & -ve & $A / G$ & $\begin{array}{l}\text { +ve/ } \\
+ \text { ve }\end{array}$ & $\begin{array}{l}\text { +ve/ } \\
+ \text { ve }\end{array}$ & +ve/+ve & Milky/lobate & $\begin{array}{l}\text { +ve (pale } \\
\text { yellow) }\end{array}$ & -ve & 7 \\
\hline$C y . s p$ & $\begin{array}{l}\text { +ve } \\
\text { (cocco- } \\
\text { bacilli } \\
\text { rods) }\end{array}$ & -ve & tve & tve & -ve & $\mathrm{A} / \mathrm{G}$ & $\begin{array}{l}\text { +ve/ } \\
+\mathrm{ve}\end{array}$ & $-v e$ & -ve/-ve & $\begin{array}{l}\text { Cream/ } \\
\text { raised }\end{array}$ & +ve (pink) & -ve & 9 \\
\hline Lac. sp & $\begin{array}{l}+ \text { ve } \\
\text { (bacilli) }\end{array}$ & +ve & tve & tve & -ve & $\mathrm{K} / \mathrm{NF}$ & $\begin{array}{l}\text { +ve/ } \\
\text { +ve }\end{array}$ & $\begin{array}{l}\text {-ve/ } \\
\text {-ve }\end{array}$ & $-v e /+v e$ & $\begin{array}{l}\text { Cream/ } \\
\text { lobate }\end{array}$ & -ve & -ve & 17 \\
\hline
\end{tabular}

Keys: $\mathrm{I}=\mathrm{Isolates}, \mathrm{A} . \mathrm{sp}=$ Acinetobacter sp, St. $\mathrm{sp}=$ Streptococcus sp, Cy. sp $=$ Corynebacterium sp, Lac. $\mathrm{Sp}=$ Lactobacillus sp, Lac $=$ Lactose, Glu $=$ Glucose, Suc $=\mathrm{Sucrose}$, Mann $=$ Mannitol, TSI $=$ Triple Salt Iron, $\mathrm{O} / \mathrm{C}=$ Oxidase $/$ Catalase test, M.t. $/ \mathrm{Sp} . \mathrm{T}=$ Motility test $/$ Spore test, MR $/ \mathrm{VP}=$ Methyl red $/$ Voges Proskauer, NA $=$ Nutrient Agar, Mac A $=$ MacConkey Agar, YEA $=$ Yeast Extract Agar, - ve $=$ negative, $+\mathrm{ve}=$ positive, $\mathrm{A} / \mathrm{G}=\mathrm{Acid} / \mathrm{GaS}, \mathrm{K} / \mathrm{NF}=$ Alkaline slant $/$ No fermentation

Table 2: Morphological and cultural characteristics of fungi isolates from the samples

\begin{tabular}{|c|c|c|c|c|}
\hline \multirow[t]{2}{*}{ RIC } & \multicolumn{2}{|c|}{ Characteristics } & \multirow[t]{2}{*}{ Fungi species } & \multirow[t]{2}{*}{ No of isolates } \\
\hline & Cultural & Morphological & & \\
\hline 1 & $\begin{array}{l}\text { Fastidious white } \quad \text { flattened } \\
\text { mycelium which becomes } \\
\text { brownish grey with age having } \\
\text { tall and short projection centers }\end{array}$ & $\begin{array}{l}\text { Sporangiophores branched in } \\
\text { simple monopodial forms, } \\
\text { appearance of non-septate hyphae } \\
\text { with smooth edged zygospores }\end{array}$ & $\begin{array}{l}\text { Fusarium } \\
\text { fujikuroi }\end{array}$ & 5 \\
\hline 2 & $\begin{array}{l}\text { Fastidious stained } \\
\text { mycelium with brownish black } \\
\text { centers that spreads rapidly }\end{array}$ & $\begin{array}{l}\text { Long thin walled hyaline } \\
\text { conidiophores with globose radiate } \\
\text { heads appear smooth with black } \\
\text { bars; conidiophores are branched } \\
\text { and lumped with cylindrical } \\
\text { phalides }\end{array}$ & Aspergillus niger & 8 \\
\hline 3 & $\begin{array}{l}\text { Fastidious white fluffy mycelium } \\
\text { with dark green velvety centers }\end{array}$ & $\begin{array}{l}\text { Globose smooth walled, non- } \\
\text { septate conidia observed with } \\
\text { biserate radiate head }\end{array}$ & $\begin{array}{l}\text { Geotrichum } \\
\text { tropicum }\end{array}$ & 3 \\
\hline 4 & $\begin{array}{l}\text { Peachy velvety spreading aerial } \\
\text { mycelium with brown edges that } \\
\text { appear dark yellowish as culture } \\
\text { ages }\end{array}$ & $\begin{array}{l}\text { Long thin walled conidiophores with } \\
\text { fusiform conidia that appears } \\
\text { convex at the apex. Hyphae is } \\
\text { hyaline with branched } \\
\text { monophalides }\end{array}$ & $\begin{array}{l}\text { Fusarium } \\
\text { oxysporum }\end{array}$ & 6 \\
\hline
\end{tabular}

Keys: RIC- Representative Isolate Clones from different sampling points 
Table 3: Zones of inhibition and antibiotic resistance patterns of characterized bacterial isolates

\begin{tabular}{|c|c|c|c|c|c|c|c|c|c|c|}
\hline \multirow[t]{2}{*}{ A.t. } & \multicolumn{5}{|c|}{ Zones of inhibition (mm) } & \multirow[t]{2}{*}{ Antibiotic class } & \multicolumn{4}{|c|}{ Resistance patterns } \\
\hline & Cy. sp. & A. sp. & St. sp. & Lac. sp. & $\begin{array}{l}\text { S. aureus } \\
\text { Control }\end{array}$ & & Cy. sp. & A. sp. & St. sp. & Lac. Sp \\
\hline ERY & $3.20 \pm 1.08^{\mathrm{a}}$ & $5.33 \pm 1.46^{\mathrm{a}}$ & $3.34 \pm 1.02^{\mathrm{a}}$ & $9.24 \pm 1.28^{\mathrm{a}}$ & $22-30$ & Macrolide & $\mathrm{R}$ & $R$ & $R$ & I \\
\hline $\mathrm{CPX}$ & $6.23 \pm 1.26^{\mathrm{b}}$ & $8.48 \pm 1.31^{\mathrm{a}}$ & $9.42 \pm 1.21^{b}$ & $13.44 \pm 1.28^{\mathrm{b}}$ & $22-30$ & Fluoroquinolone & $\mathrm{R}$ & I & $\mathrm{R}$ & I \\
\hline COT & $8.44 \pm 1.22^{\mathrm{b}}$ & $5.08 \pm 1.23^{\mathrm{a}}$ & $5.81 \pm 1.09^{a}$ & $7.28 \pm 1.19^{\mathrm{a}}$ & $24-32$ & Cotrimoxazole & $\mathrm{R}$ & $\mathrm{R}$ & $\mathrm{R}$ & $\mathrm{R}$ \\
\hline AMX & $3.87 \pm 0.24^{\mathrm{a}}$ & $11.26 \pm 1.82^{\mathrm{b}}$ & $4.51 \pm 1.05^{\mathrm{a}}$ & $10.72 \pm 1.48^{\mathrm{b}}$ & - & Penicillin & $\mathrm{R}$ & I & $\mathrm{R}$ & I \\
\hline OFL & $19.29 \pm 1.22^{\mathrm{e}}$ & $18.46 \pm 1.70^{c}$ & $11.43 \pm 1.81^{\mathrm{c}}$ & $20.59 \pm 1.22^{c}$ & $24-28$ & Quinolone & $\mathrm{S}$ & S & I & S \\
\hline STR & $12.13 \pm 1.28^{\mathrm{d}}$ & $14.23 \pm 1.59^{b}$ & $6.52 \pm 1.28^{\mathrm{a}}$ & $18.35 \pm 1.14^{c}$ & $14-22$ & Aminoglycoside & I & I & $\mathrm{R}$ & S \\
\hline $\mathrm{CHL}$ & $7.83 \pm 1.81^{b}$ & $16.55 \pm 1.31^{\mathrm{c}}$ & $12.99 \pm 1.01^{\mathrm{c}}$ & $11.23 \pm 1.71^{b}$ & $19-26$ & Chloramphenicol & $\mathrm{R}$ & S & I & I \\
\hline CEF & $9.28 \pm 1.22^{\mathrm{b}}$ & $13.36 \pm 1.29^{b}$ & $6.41 \pm 1.66^{\mathrm{a}}$ & $6.67 \pm 1.31^{\mathrm{a}}$ & $22-28$ & Cephalosporin & $\mathrm{R}$ & I & $\mathrm{R}$ & $\mathrm{R}$ \\
\hline GEN & $5.29 \pm 1.48^{\mathrm{a}}$ & $13.79 \pm 1.52^{\mathrm{b}}$ & $14.55 \pm 1.05^{\mathrm{c}}$ & $14.51 \pm 1.39^{\mathrm{b}}$ & $19-27$ & Aminoglycoside & $\mathrm{R}$ & I & I & I \\
\hline PEF & $18.10 \pm 1.34^{\mathrm{e}}$ & $19.26 \pm 1.58^{c}$ & $20.35 \pm 1.28^{d}$ & $19.21 \pm 1.21^{\mathrm{c}}$ & - & Fluoroquinolone & $\mathrm{S}$ & $\mathrm{S}$ & $\mathrm{S}$ & $\mathrm{S}$ \\
\hline & & The iso & s; $C y$. sp. and & $\mathrm{sp}$. are resistar & to more thar & 2 antibiotics class & S (MDRIs) & & & \\
\hline
\end{tabular}

Table 4: Antagonistic patterns of bacteria isolates against selected clinical pathogens

\begin{tabular}{|c|c|c|c|c|c|c|c|}
\hline \multirow[t]{2}{*}{ Bacteria isolate } & \multicolumn{3}{|c|}{ Observed antagonistic interaction (mm) } & \multicolumn{4}{|c|}{ Deduced antagonistic patterns } \\
\hline & Salmonella sp & $\begin{array}{c}\text { Staphylococcus } \\
\text { aureus }\end{array}$ & $\begin{array}{l}\text { Streptococcus } \\
\text { pyogenes }\end{array}$ & *Control strain & Salmonella sp & $\begin{array}{c}\text { Staphylococcus } \\
\text { aureus }\end{array}$ & $\begin{array}{l}\text { Streptococcus } \\
\text { pyogenes }\end{array}$ \\
\hline Acinetobacter sp. & $00 \pm 00^{\mathrm{a}}$ & $9.36 \pm 1.45^{b}$ & $13.23 \pm 1.54^{c}$ & $+v e$ & -ve & -ve & I \\
\hline Streptococcus sp. & $2.12 \pm 0.29^{a}$ & $5.58 \pm 1.64^{b}$ & $00 \pm 00^{\mathrm{a}}$ & $-v e$ & -ve & $-v e$ & -ve \\
\hline Corynebacterium sp. & $00 \pm 00^{\mathrm{a}}$ & $00 \pm 00^{\mathrm{a}}$ & $6.84 \pm 1.23^{b}$ & I & -ve & -ve & -ve \\
\hline Lactobacillus sp. & $14.34 \pm 1.53^{b}$ & $12.82 \pm 1.68^{c}$ & $16.19 \pm 1.21^{d}$ & +ve & I & I & $+v e$ \\
\hline
\end{tabular}

I= Intermediate; -ve= Negative antagonism or no antagonistic interaction; +ve= Positive antagonism; values with the same letter as superscript are not significantly different $(p>$ 0.05). *Haemophilus influenzae ATCC 49247

Table 5: Antagonistic patterns of fungal isolates against selected clinical pathogens

\begin{tabular}{|c|c|c|c|c|c|c|c|}
\hline \multirow[t]{2}{*}{ Fungal isolates } & \multicolumn{3}{|c|}{ Observed antagonistic interaction (mm) } & \multicolumn{4}{|c|}{ Deduced antagonistic patterns } \\
\hline & Salmonella sp & $\begin{array}{c}\text { Staphylococcus } \\
\text { aureus }\end{array}$ & $\begin{array}{c}\text { Streptococcus } \\
\text { pyogenes }\end{array}$ & $*$ Control strain & Salmonella sp & $\begin{array}{c}\text { Staphylococcus } \\
\text { aureus }\end{array}$ & $\begin{array}{c}\text { Streptococcus } \\
\text { pyogenes }\end{array}$ \\
\hline A. niger & $14.01 \pm 1.03^{c}$ & $9.23 \pm 1.76^{\mathrm{a}}$ & $18.21 \pm 1.48^{c}$ & I & I & -ve & $+\mathrm{ve}$ \\
\hline F. oxysporium & $8.42 \pm 1.48^{b}$ & $12.08 \pm 1.82^{b}$ & $11.28 \pm 1.56^{b}$ & I & $-v e$ & $-v e$ & I \\
\hline F. fujikuroi & $00 \pm 00^{\mathrm{a}}$ & $13.25 \pm 1.74^{\mathrm{b}}$ & $17.56 \pm 1.67^{c}$ & $+v e$ & $-v e$ & I & +ve \\
\hline G. condidum & $11.91 \pm 1.66^{c}$ & $18.91 \pm 1.33^{\mathrm{c}}$ & $00 \pm 00^{\mathrm{a}}$ & +ve & I & $+v e$ & -ve \\
\hline
\end{tabular}

Keys: A. niger=Aspergillus niger; F. oxysporium=Fusarium oxysporium; F. fujikuroi=Fusarium fujikuroi; G. condidum=Geotrichum condidum; $\mathrm{I}=$ Intermediate; -ve= Negative antagonism or no antagonistic interaction; +ve= Positive antagonism; values with the same letter as superscript are not significantly different $(p>0.05)$. *Candida parapsilosis ATCC 22019 
Table 6: Zones of inhibition and antibiotic susceptibility patterns of MDRIs post plasmid curing

\begin{tabular}{|c|c|c|c|c|}
\hline \multirow[t]{2}{*}{ Antibiotics } & \multicolumn{2}{|c|}{ Zones of inhibition (mm) } & \multicolumn{2}{|c|}{ Susceptibility patterns } \\
\hline & Corynebacterium sp & Streptococcus sp & Corynebacterium sp & Streptococcus sp \\
\hline ERY & $17.15 \pm 1.82^{\mathrm{a}}$ & $18.15 \pm 1.82^{a}$ & $S$ & $\mathrm{~S}$ \\
\hline CPX & $19.31 \pm 1.61^{\mathrm{a}}$ & $17.43 \pm 1.19^{a}$ & S & S \\
\hline СOT & $18.33 \pm 1.28^{\mathrm{a}}$ & $19.21 \pm 1.48^{\mathrm{a}}$ & $S$ & S \\
\hline AMX & $15.78 \pm 1.09^{a}$ & $17.44 \pm 1.29^{a}$ & S & S \\
\hline OFL & $19.85 \pm 1.45^{\mathrm{a}}$ & $16.89 \pm 1.75^{\mathrm{a}}$ & S & S \\
\hline STR & $18.67 \pm 1.46^{\mathrm{a}}$ & $19.27 \pm 1.84^{\mathrm{a}}$ & S & $\mathrm{S}$ \\
\hline $\mathrm{CHL}$ & $19.59 \pm 1.08^{a}$ & $19.78 \pm 1.33^{\mathrm{a}}$ & S & S \\
\hline CEF & $20.18 \pm 1.84^{\mathrm{a}}$ & $21.18 \pm 1.24^{\mathrm{a}}$ & S & S \\
\hline GEN & $18.58 \pm 1.42^{\mathrm{a}}$ & $18.47 \pm 1.96^{\mathrm{a}}$ & $S$ & S \\
\hline PEF & $19.29 \pm 1.71^{\mathrm{a}}$ & $19.46 \pm 1.84^{\mathrm{a}}$ & S & S \\
\hline
\end{tabular}

Keys: COT=Cotrimoxazole; $\mathrm{CPX}=$ Ciprofloxacin; $\mathrm{ERY}=$ Erythromycin; $\mathrm{AMX}=$ Amoxycillin; OFL= Ofloxacin; STR= Streptomycin; $\mathrm{CHL}=$ Chloramphenicol; $\mathrm{CEF}=$ Ceftriaxone; $\mathrm{GEN}=$ Gentamycin; PEF= Pefloxacin; R- Resistant; I- Intermediate; S- susceptible; MDRIs- Multiple antibiotic resistant isolates; values with the same letter as superscript have no significant difference at $p \leq 0.05$ level of significance.; R- Resistant; I- Intermediate; S- susceptible. MDRIs- Multiple drug resistant isolates, values with the same letter as superscript have no significant difference at $(p>0.05)$

\section{Discussion:}

The microorganisms identified from this study showed that termite nests have high microbial diversity. Some of the organisms obtained in this study such as Corynebacterium $\mathrm{sp}$, Acinetobacter sp, Streptococcus sp, Aspergillus niger and Geotrichum condidum have been investigated in studies on termite nest micro flora, most especially by Afolami et al,. (1) and Aribisala et al., (2) where authors recently embarked on a similar work. Fungi isolates obtained in this study such as Fusarium oxysporium and Aspergillus niger produce mycotoxins which are of pathological importance to kola nut trees and termites alike, although recent reports by Afolami et al., (1) and Aribisala et al,. (2) may suggest that these fungi would also directly impact economic losses and effects on crop plants, animals and humans.

A previous report by Bignell et al., (21) suggested that termites may harbor microaerophilic bacteria that aid cellulose digestion and this underscores the benefit the mutuallistic relationship between termites and bacteria inhabiting their guts. Our study underscored this claim since the bacteria Acinetobacter sp and Corynebacterium sp obt- ined from the study are micro-aerophilic (5). The study by Lo and Eggleton (22) also affirmed that termites use faecal matter to make internal ventilating structures (combs) which act as substrates for the growth of the symbiotic fungi in their nests. This corroborate the presence of soil borne fungi, $A$. niger, $F$. oxysporum, $F$. fujikuroi and $G$. condidum obtained from our study.

Earlier reports by Afolami et al., (1) and Aribisala et al., (2) observed that termites might develop defensive strategies against invading pathogens by producing antimicrobial substances in defensive glandular secretions which allow them resist termite borne pathogens over an extensive period of time. It might be safe to suggest that these previous reports explain why all the bacterial isolates obtained from termite nests have varying degrees of antibiotic resistance since they may have been exposed previously to wide range antimicrobial substances from termite secretions and insecticide sprays prior to this study. This may also partly give a scientific explanation to uncorroborated claims made by local respondents about the potency of termite based herbal concoction in treating paediatric infections. However, the results also presented showed that these locally made herbal 
concoctions used by local dwellers may pose serious health risks since bacteria in this study showed stellar multiple antibiotic resistance and respondents risk ingestion of these MDRIs.

Consequently, the susceptibility patterns of the bacteria isolates observed in our study might have resulted from exposure of termite nests on kola nut barks to active components in many herbicides used by local farmers, which may be similar to the compounds present in the antibiotics used in our study. This may trigger a form of acquired antibiotic resistance in the isolates. Similar observations have been made by Brune and Dietrich (23), Afolami et al., (1) and Aribisala et al., (2). As observed in our study, plasmidmediated antibiotic resistance mechanisms might have been responsible for resistance in the MDRIs, which could manifest as antibiotic efflux, gene mutation, and aberrant protein expressions that reduce permeability of bacteria cell envelopes to many antibiotics, resulting in resistance (24).

Local residents from Ipogun community have described clinical symptoms suggestive of acute typhoid fever and infantile food poisoning in children, attributed to Salmonella sp, S. aureus and $S$. pyogenes (personal communication). Meanwhile, similar infection patterns caused by pathogens used in our study have also been previously reported by the local health authorities of the affected area, which informed the testing of isolates we obtained from termite tubes in our study against these pathogens. Rabasa et al., (25) described the clinical presentations of acute salmonellosis in infants as a case study in western Nigeria (same region of the affected community) while Shittu et al., (26) and Odigwe et al., (27) suggested that infants (below age 9) may be more susceptible to haemolytic infections and food poisoning in Nigerian communities where basic life amenities are inadequate. Rural communities such as Ipogun (the study area) lack basic amenities. Hence, it is not surprising that the rising incidence of paediatric infections in this community had defied antibiotic interventions. This explains why the local residents affected sought for traditional indigenous medical interventions.

Since this study aims at corroborating claims made by local residents, the authors cited the report of Holt and Leepage (4) suggesting that microorganisms inhabiting the termite guts are capable of exhibiting overt antagonisms against other pathogens as part of their adaptation. Hence, Lactobacillus sp, F. fujikuroi and $G$. condidum showed mild antagonism against the pathogens tested. The antagonisms exhibited by Lactobacillus sp may be due to the production of antimicrobials such as bacteriocins and lactic acid derivatives that can hinder the metabolism of the pathogens, while the fungal isolates ( $F$. fujikuroi and $G$. condidum) are producers of lytic enzymes and toxic exudates that can lyse cell walls of pathogens (24).

Although previous reports by Afolami et al., (1) and Aribisala et al., (2) described antagonistic patterns of isolated organisms from Mango and Cocoa trees in Ibule-soro, the findings presented in this current study showed antagonisms of Lactobacillus sp and certain fungi ( $F$. fujikuroi and $G$. condidum) from termite nests on kola nut trees in a different community (Ipogun). This made the current study better defined in scope for a new study area than previous studies. Hence, the antagonisms observed in this study clearly establish termite tubes to contain certain microbes that may aid inhibitory properties of the local medicine formula adopted by rural dwellers in this affected community against pathogens causing infantile infections in their community.

\section{Conclusion:}

This study has shown that Lactobacillus sp and certain fungi contained in termite nests on kola nut trees possess antagonistic potentials against pathogens obtained from paediatric patients and that some bacteria present in termite guts may possess overt multiple drug resistances due to their carriage of resistant plasmids.

\section{Acknowledgements:}

The authors acknowledge the immense contributions of Mr. Babajide Ajayi of the Department of Microbiology, Federal University of Technology Akure, Ondo state, Nigeria during the course of this research.

\section{Conflict of interest/source of fund:}

There are no conflicts of interests and the authors received no funding from any organization or persons for the research.

\section{References:}

1. Afolami, O., Aribisala, J., Oladunmoye, M., Wasiu, O., and Arogundade, I. Characterization, antibiotic sensitivity patterns, plasmid profile analysis and 
antagonistic potentials of microorganisms from termitaria on mango trees in Ibule-Soro, Akure, Nigeria. Acta Sci Microbiol. 2018; 1(3): 2-7.

2. Aribisala, J., Oladunmoye, M., Afolami, O., and Aina, T. Identification, antagonistic potentials and plasmid profiling of microorganisms associated with termitarium from cocoa trees in Ibule-soro, Akure, Nigeria. Acta Sci Microbiol. 2018; 1(3): 812.

3. Toledo, M., Lima, J., and Costa-Leonardo, A. Subterranean termites (Isoptera: Rhinotermitidae): Exploitation of equivalent food resources with different forms of placement. Insect Sci. 2012; 19(3): 412-418.

4. Holt, J., and Leepage, M. Termites and soil properties: Evolution, sociology, symbiosis, ecology. Kluwer Academic Publishers, Amsterdam, Netherlands, 2000.

5. Brune, A. Symbiotic digestion of lignocellulose in termite guts. Nat Annual Rev Microbiol. 2014; 12 168- 180.

6. Aiki, P., Majeed, Q., Adamu, T., Bandiya, H., and Suleiman, M. A survey of termite species found within Zuru Local government of Kebbi State, Nigeria. Int J App Res and Tech. 2013; 2(6): 169173.

7. Sonibare, A., Soladoye, M., Oyedokun, E., and Oluwadayo, S. Phytochemical and Antimicrobia Studies of Four Species of Cola Schott and Endl. (Sterculiaceae). Afr J Trad Complementary Altern Med. 2009; 6(4): 518-525.

8. Agbelade, A., and Akindele, S. Land Use Mapping and Tree species diversity of Federal University of Technology Akure. Am Int J Contemporary Res. 2013; 3(2): 104-113.

9. Barreto, J., Trevisan, M., Hall, W., et al. Characterization and quantification of bacteria and polyphenols from bark, kernel, leaves and peel of mango (Magnifera indica). J Agric and Food Chem. 2008; 56(4): 5599-5610.

10. Fawole, M., and Oso, B. Laboratory Manual on Microbiological Practices. Ibadan, Nigeria, 2007.

11. Vivyan, E., Hedges, R., and Datta, N. Two modes of curing transmissible bacterial plasmids. J Gen Microbiol. 1972; 70: 443-452.

12. Samson, R., Houbraken, J., Thrane, U., Frisvad, C., and Anderson, B. A laboratory manual series of food, indoor, air and soil fungi: a compendium of fungi biodiversity. Fungal Biodiversity Center, Utrecht, Amsterdam Royal Academy, Netherlands, 2010.

13. Onifade, A., Omoya, F., Afolami, O., Fabowale, P., Ladenika, O., and Agunloye, O. Investigation on the Comparative Diversity and Public Health Significance of Soil and Air Mycoflora of Federal University of Technology Campus, Akure, Nigeria. Asian J Biotech and Biores Tech. 2017; 2(3): 111.

14. Onifade, A., and Afolami, O. Antibiotic resistance patterns of Salmonella sp from clinical and water sources in Akure, Ondo State, Nigeria. Asian J Res Med Pharm Sci. 2018; 5(1): 1-10. National Committee for Clinical Laboratory Standards (NCCLS). Performance Standards for Antimicrobial Disk Susceptibility Testing, 10 Information Supplement Approved Standard, M100-S10, Wayne PA. USA, 2002.

16. Akingbade, O., Balogun, S., Ojo, D., Akinduti, P. Okerentugba, O., Nwanze, C., and Okonko, I. Resistant plasmid profile analysis of multidrug resistant Escherichia coli isolated from urinary tract infections in Abeokuta, Nigeria. Afr Hith Sci. $2014 ; 14(4)$ : 821-826.

17. Birnboim, H., and Dolly, J. A rapid alkaline extraction procedure for screening recombinant plasmid DNA. Nucl Acids Res. 1997; 45(7): 1513-
1523.

18. Fokkema, N., and Heuvel, J. Microbiology of the Phyllosphere and guidelines for fungal antagonistic assays. Cambridge University Press, New York, 1996.

19 Clinical Laboratory Standard Institute (CLSI) Reference method for broth dilution antifungal susceptibility testing of yeasts; 4th informational supplement. CLSI document M27-S4 CLSI, Wayne, PA, 2012.

20. Jabeen, K., Kumar, H., Farooqi, J., Mehboob, R., Brandt, M., and Zafar, A. Agreement of direct antifungal susceptibility testing from positive blood culture bottles with the conventional method for Candida species. J Clin Microbiol. 2016; 54:343-348.

21. Bignell, D., Roisin, Y., and Lo, N. Biology of Termites: a Modern Synthesis. Springer, PubMed., New York, 2010

22. Lo, N. and Eggleton, P. Termite phylogenetics and co-cladogenesis with symbionts, in Biology of Termites: A Modern Synthesis. New York City, Springer, 2011.

23. Brune, A. and Dietrich, C. The gut microbiota of termites: digesting in the light of ecology and evolution. Annual Rev Microbiol. 2015; 69: 145166.

24. Peterson, F., Stewart, L., and Scharf, E. Quantifying symbiotic contributions to lower termite digestion using antimicrobial compounds. Insect Biochem Mol Biol. 2015; 59: 80-88.

25. Rabasa, A., Mava, Y., Pius, S., Timothy, D., and Baba, A. Typhoid fever in children: clinical presentation and risk factors in western Nigeria. Niger J. Paed. 2013; 40(1): 60-63.

26. Shittu, A., Lin, J., and Kolawole, D. Antimicrobial Susceptibility patterns of Staphylococcus aureus and characterization of MRSA in south-western Nigeria. Wounds. 2006; 18(4): 77-84.

27. Odigwe, C., Udo, M., and Ohia, N. Association of Acute Sore Throat with Group A Beta Hemolytic Streptococci carriage among Children in a Public School in Calabar. Global J Med Sci. 2002; 4(2): 55-59. 